Bulgarian Academy of Sciences. Space Research and Technology Institute.

Aerospace Research in Bulgaria. 32, 2020, Sofia

DOI: https://doi.org/10.3897/arb.v32.e03

\title{
WATER SURFACE DYNAMIC'S OF THE STUDENA DAM, PERNIK USING SENTINEL 2A AND 2B SATELLITE DATA
}

\author{
Georgi Jelev \\ Space Research and Technology Institute - Bulgarian Academy of Sciences \\ e-mail:g_jelev@space.bas.bg
}

Keywords: Water Surface, Studena Dam, Sentinel-2

\begin{abstract}
This article presents the results of a study of the dynamics of the surface water area of the Studena dam using satellite images from Sentinel $2 A$ and $2 B$. The period considered is from the beginning of 2019 to January 2020. The collected 35 cloud-free images from a total of 80 captured are organized in a spatial database in a GIS environment. A water index - MNDWI (Modified Normalized Difference Water) was used to determine the boundary of the water surface. The calculated areas for all images and their trends are analyzed by graph. For about seven months from the maximum annual area $\left(0.91 \mathrm{~km}^{2}\right)$ in June, a rapid decrease of $0.10 \mathrm{~km}^{2}$ per month is observed until the beginning of 2020 , when the lowest value was measured $-0.23 \mathrm{~km}^{2}$.
\end{abstract}

\section{Introduction}

The Studena Dam is located at the western end of Vitosha Mountain. It was built in the period 1953-1955 and was put into operation in 1955 for the purpose of water supply to the town of Pernik and the region. It is located on the Struma River next to the village of Studena and is part of the water balance of Vitosha Nature Park, [1-3]. It is therefore not allowed to fish and is protected. The area is 145.6 ha $\left(1.456 \mathrm{~km}^{2}\right)$ [I.1]. During its operation, the amount of water (volume) and contour of the water mirror varied greatly. In the period 1982-1994, it decreased by half, with a decrease below the dead volume recorded in December 1993 to March 1994 [4]. In their study [5], the authors identified periods and conditions of longer drought of the dam, considering the period 2001-2017. Due to the endangering low quantities of water remaining and the growing social problem, the use of remote methods gives us reliable and accurate information about the dynamics of the water surface of the dam. 


\section{Study area}

The study area is the Studena Dam, located at the western end of Vitosha Mountain, southwest of Sofia, near Pernik (Fig. 1). The specific purpose of the study is to track and analyze the dynamics of the water surface of the dam for 2019.

\section{Materials and Methods}

Images of European Sentinel-2A and Sentinel-2B satellites [I.2], launched under the Copernicus program, formerly known as GMES (Global Monitoring for Environment and Security), and were used to study the dynamics of the water surface of Studena dam. It is the European Earth observation and monitoring capacity building program [I.3].

The data from this pair of satellites is appropriate because of its high temporal resolution - every 5 days. The images are $10 \mathrm{~m}, 20 \mathrm{~m}$ and $60 \mathrm{~m}$ in spatial resolution. Each of the satellites is equipped with a multispectral sensor (MSI) with 13 spectral channels in the visible, near infrared (VNIR) and shortwave infrared (SWIR) (Table 1). The available spectral channels are suitable for accurate determination of the water-land boundary $[6,7]$. Access to the image databases from the Copernicus Open Access Hub is free [I.2].

Table 1. Sentinel-2 spectral bands and spatial resolutions [I.4]

\begin{tabular}{|c|c|c|c|}
\hline $\begin{array}{c}\text { Band number } \\
(\mathbf{\rho})\end{array}$ & $\begin{array}{c}\text { Central wavelength } \\
(\mathbf{n m})\end{array}$ & $\begin{array}{c}\text { Band width } \\
(\mathbf{n m})\end{array}$ & $\begin{array}{c}\text { Spatial resolution } \\
(\mathbf{m})\end{array}$ \\
\hline 1 & 443 & 20 & 60 \\
\hline 2 & 490 & 65 & 10 \\
\hline $\mathbf{3}(\mathbf{G R E E N})$ & $\mathbf{5 6 0}$ & $\mathbf{3 5}$ & $\mathbf{1 0}$ \\
\hline 4 & 665 & 30 & 10 \\
\hline 5 & 705 & 15 & 20 \\
\hline 6 & 740 & 15 & 20 \\
\hline 7 & 783 & 20 & 20 \\
\hline 8 & 842 & 115 & 10 \\
\hline $8 \mathrm{a}$ & 865 & 20 & 20 \\
\hline 9 & 945 & 20 & 60 \\
\hline 10 & 1380 & 30 & 60 \\
\hline $\mathbf{1 1}(\mathbf{S W I R})$ & $\mathbf{1 6 1 0}$ & $\mathbf{9 0}$ & $\mathbf{2 0}$ \\
\hline 12 & 2190 & 180 & 20 \\
\hline
\end{tabular}

A GIS database was created - a geographic information system for monitoring the Studena dam by satellite images.

The use of satellite images gives a true idea of the objects on the Earth's surface and their change over time and is a reliable source of information [6-8]. In this article, they are used to accurately estimate the change in the water surface area 
of the Studena dam for the last one year. To determine the maximum water surface of the dam, a topographic map K-34-059-1 - Pernik [I.5] and an image from Google Earth, Image (C) 2020 Maxar Technologies, dated July 30, 2013, were used (Fig. 1) [I.6].

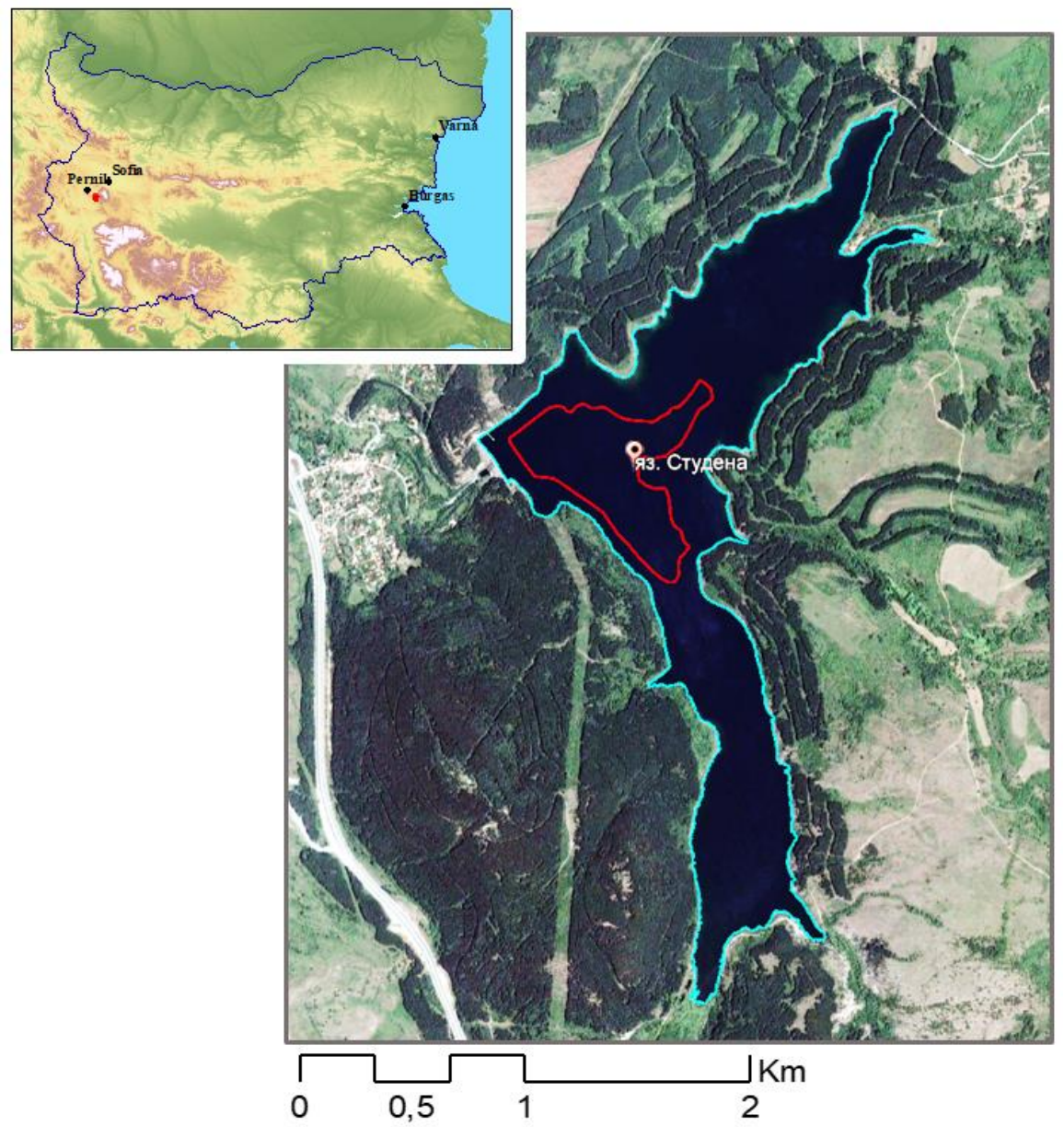

Fig. 1. Maximum $\left(1.43 \mathrm{~km}^{2}, 30.07 .2013\right)$ and minimum $\left(0.23 \mathrm{~km}^{2}, 09.01 .2020\right)$ water surface area of Studena dam [I.5]

\section{Satellite data processing}

For more accurate identification of the water surface, the generated water index - MNDWI (Modified Normalized Difference Water) was used, which combines the advantages of maximum absorption in the shortwave spectrum and 
maximum reflection in the green spectral channel $[9,10]$. The index is calculated by the formula:

$$
\text { 1) } \quad M N D W I=\frac{\rho G R E E N-\rho S W I R}{\rho G R E E N+\rho S W I R} \text {, }
$$

Where

$\rho$ GREEN is spectral channel 3 - green $(560 \mathrm{~nm})$,

$\rho S W I R$ is a spectral channel 11 - shortwave-infrared $(1610 \mathrm{~nm})$.

Geographic information systems (GIS) capabilities have been used to automatically calculate the index and extract the boundary of the water surface of the dam, and a model has been created for this purpose (Fig. 2).

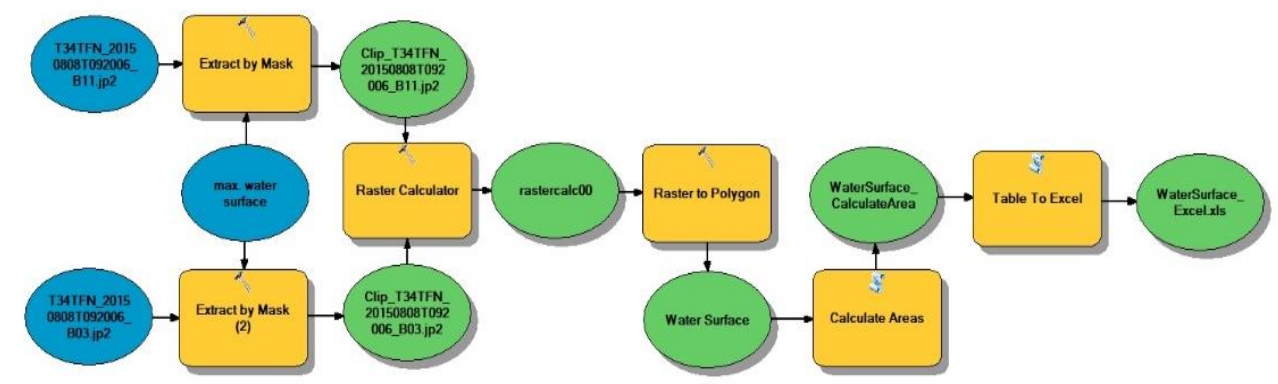

Fig. 2. Model water surface builder

\section{Results and Discussions}

The main problem with the satellite images used is the cloud cover masking effect. Only 35 cloudless images over the dam were studied from 80 taken from the Sentinel-2A and Sentinel-2B satellites during the study period (01/01/201929/01/2020). The normalized MNWI water index of formula 1) is calculated. On the basis of the obtained index images for each date, the contours of the water surface of the dam were extracted according to the model given in Fig. 2. The water surface areas have been calculated and the tendencies for stepwise decrease of their values and from there the quantities of water are clearly visible (Fig. 3).

The sharp decrease in the trends around the end of June and the beginning of July and the dates 01,11 and 21 October is noticeable. The individual trends are characterized by a sharp decrease in the area of the water surface. The first decrease is at the end of July and is within $0.09 \mathrm{~km}^{2}$. The second is with a greater difference of $0.24 \mathrm{~km}^{2}$ and is observed in the first half of September. After 5-15 November until about 15 December, a steep decline was observed (a decrease of about $0.18 \mathrm{~km}^{2}$ ), reaching a value of $0.23 \mathrm{~km}^{2}$ at the end of the year. At the beginning of 
2020 (09.01.2020) the minimum value of the water surface of the Studena Dam $0.23 \mathrm{~km}^{2}$ - was reported.

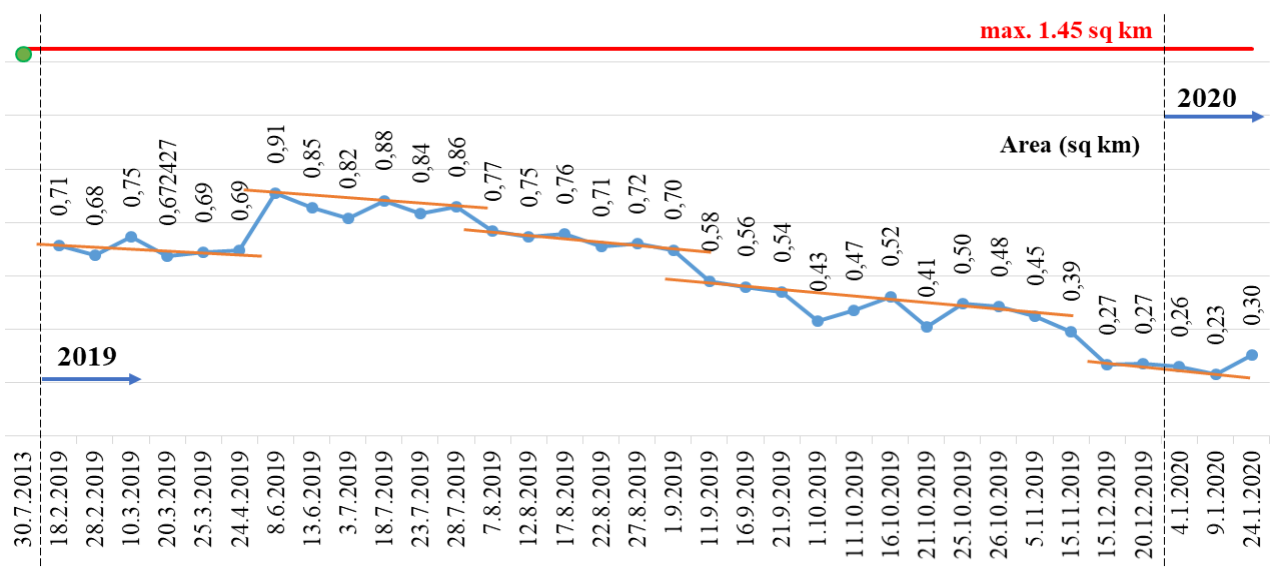

Fig. 3. Dynamics of the water surface area of the Studena dam in the studied period

In Fig. 1. the significant difference between the maximum measured in July 2013 and the minimum value in January 2020 of the water surface area of the dam is clearly visible.

The increase of the water surface at the end of January 2020, after the measures taken earlier, makes a positive impression.

The increase of the water surface area in May 2019 is clearly visible due to more rainfall (all images from May have a dense cloud cover).

\section{Conclusion}

In conclusion, the analysis of the satellite imagery data confirms the clear tendency to decrease the water surface area in 2019. There are clear sharp reductions in area and, accordingly, the amount of water around the dates 03 and $23 \mathrm{July,} 01$, 11 and 21 October, 15 December.

The upward trend at the end of January 2020 gives optimistic hope.

\section{References}

1. Bardarska, G. and H. Dobrev, 2003. Vlijanie na zasushavaneto sprjamo kachestvoto na povarhnostnite vodi, $\mathrm{v}$ Zasushavaneto $\mathrm{v}$ Balgarija: Savremenen analog za klimatichni promeni prirodni, ikonomicheski i socialni izmerenija na zasushavaneto 1982 - 1994 godina, (ed. by I. Raev, C. G. Knight and M. Staneva), 82-94. Publisher: BAS, Sofia, URL: https://www.solvo.bg/wp-content/ uploads/sush.pdf (in Bulgarian) 
2. Monev, E., R. Marinov, I. Ilcheva, and A. Yordanova, Development of Control Monitoring for the Purposes of Integrated Water Resource Management of the Vitosha Natural Park, J. of Intern. Sci. Publicat., 2015, 9, 383-93. ISSN 1314-7234.

3. Irena, I., I. Niagolov, S. Balabanova, A. Yordanova, V. Rainova, A. Vatralova, and D. Georgieva. Water Resource Balance for the Vitosha Natural Park, Including Analysis Under Conditions of Climate Change and Extreme Phenomena, International Scientific Conference Proceedings - Sustainable Mountain Regions: Make Them Work, 2015, 246-53. Publisher: Fakel, ISBN 978-954-411-220-2.

4. Rajnova, V., I. Ilcheva, and A. Jordanova, 2017. Obezpechenost na vodosnabdjavaneto za nuzhdite na turizma v predelite na park Vitosha, Science \& Technologies, Natural and Mathematical Science, 2017, VII, 3, 86-93. (in Bulgarian)

5. Irena, I., Y., Anna, and V. Rainova. Application of Standardized Status Index for Prolonged Drought Identification and River Basin Management. Socio Brains, 2019, 114-22. ISSN 2367-5721.

6. Mishra, K. and Prasad, P. R. C.. Automatic Extraction of Water Bodies from Landsat Imagery Using Perceptron Model, Journal of Computational Environmental Sciences, 2015, 903465, DOI:10.1155/2015/903465.

7. Jelev, G. and E. Roumenina. Monitoring the Studen kladenets reservoir using air and space images, Aerospace Researchin Bulgaria, 2001, 16, 97-106. SRI-BAS, http://journal.space.bas.bg/arhiv/n\%2016/Volume_16.pdf.

8. Jelev, G. and E. Roumenina, Monitoring na Jaz. "Studen kladenec" s izpolzvane na aero i kosmicheski izobrazheniJa, In: Dokladi ot nauchna konferencija s mezhdunarodno uchastie v pamet na prof. d-r Dimitar Jaranov, 2002, 2, 244-54. (in Bulgarian)

9. Casadei1, S., S. Di Francesco, F. Giannone, and A. Pierleoni. Small reservoirs for a sustainable water resources management, Adv. Geosci., 2019, 49, 165-74, DOI:10.5194/adgeo-49-165-2019.

10. Xu, H., 2006. Modification of normalized difference water index (NDWI) to enhance open water features in remotely sensed imagery, Int. J. Remote Sens., 27, 3025-33, DOI:10.1080/01431160600589179.

\section{Internet Sources}

I.1.https://bg.wikipedia.org/ - Wikipedia, the free encyclopedia

I.2. https://scihub.copernicus.eu/dhus/\#/home - Copernicus Open Access Hub

I.3. https://www.copernicus.eu/bg - Copernicus Home page

I.4. https://earth.esa.int/web/sentinel/technical-guides/sentinel-2-msi/msi-instrument -

"Multi Spectral Instrument (MSI) Overview". Sentinel Online. ESA.

I.5. http://web.uni-plovdiv.bg/vedrin/details/K-34-059-1.html - Topographic map archives at 1: 50000 scale.

I.6. https://www.google.com/maps/ - Google Earth map, Image (c) 2020 Maxar Technologies 


\section{ДИНАМИКА НА ВОДНАТА ПОВЪРХНОСТ НА ЯЗОВИР СТУДЕНА, ГР. ПЕРНИК С ИЗПОЛЗВАНЕ НА ИЗОБРАЖЕНИЯ OT SENTINEL 2A и 2B}

\section{Г. Желев}

\section{Резюме}

В тази статия са представени резултати от изследване на динамиката на площта на водната повърхност на язовир „Студена“ с използване на спътникови изображения от Sentinel-2A, -2B. Разгледаният период е от началото на 2019 г. до януари 2020 г. Събраните 24 броя изображения са организирани в пространствена база данни в среда на ГИС. Използван е воден индекс MNDWI (Modified Normalized Difference Water), с помощта на който е определена границата на водната повърхност. Изчислените площи за всички изображения и техните тенденции са анализирани чрез графика. За около седем месеца от максималната за годината площ през месец юни се вижда бързото намаляване със средно $0.10 \mathrm{~km}^{2}$ месечно до началото на 2020 г., когато на 09 януари е измерена най-ниската стойност $-0.23 \mathrm{~km}^{2}$. 